\title{
An evaluation of the effects of extended grazing pasture with ewe lambs on sward botanical composition
}

TWJ Keady ${ }^{1}$, J Moran $^{2}$, JP Hanrahan $^{1}$

${ }^{1}$ Teagasc, Athenry, Co. Galway, Ireland, ${ }^{2}$ Institute of Technology Sligo, Baallinode, Sligo, Ireland

Email:tim.keady@teagasc.ie

Introduction Previous studies at this centre have shown that extended (deferred, winter) grazing ewes in mid (Keady et al 2007, Keady and Hanrahan 2009b) late (Keady et al 2007) or throughout (Keady et al 2007, Keady and Hanrahan 2009a) pregnancy increased lamb birth and weaning weights relative to progeny from ewes which were housed unshorn. However Keady et al (2009) concluded that whilst year round grazing provided a viable system for sheep production, stocking rate had to be dramatically reduced relative to systems in which ewes were housed and offered conserved forage during the winter feeding period. During extended grazing, ewes graze pasture with heavy sward cover, at set herbage allowances which are normally allocated either daily or twice weekly. Furthermore extended grazing occurs during the winter months which are normally associated with high rainfall. Consequently pasture becomes soiled and poaching can occur. There is circumstantial evidence that extended grazing has a negative impact on subsequent sward botanical composition. The aim of the current study was to evaluate the effects of extended grazing on subsequent sward composition.

Materials and methods A sward which had been harvested for silage in early September received fertiliser N at $34 \mathrm{~kg} / \mathrm{ha}$ for extended grazing between 12-18 December, 16-22 January and 20-26 February. One hundred and two ewe lambs (40.9 $\mathrm{kg}$ ) were allocated to two grazing herbage DM allowances of 0.75 and $1.75 \mathrm{~kg} \mathrm{DM} / \mathrm{hd}$ daily $(0.75 \mathrm{G}$ and $1.75 \mathrm{G})$. During extended grazing fresh herbage was allocated daily. Within each herbage allowance area a $0.5 \mathrm{~m} \times 1 \mathrm{~m}$ plot was mowed to $3 \mathrm{~cm}$ in early December (A) and a second $0.5 \mathrm{~m} \mathrm{x} 1 \mathrm{~m}$ plot was mowed on the day of extended grazing (B). These plots were protected by mesh cages during grazing. Herbage yield and vascular plant botanical composition was determined for treatments $\mathrm{A}, \mathrm{B}, 0.75 \mathrm{G}$ and $1.75 \mathrm{G}$ at 25 points $(20 \mathrm{~cm}$ intervals $)$ using a point quadrat for 19 plots per treatment, between 23 and 27 April. The data were analysed, using SAS, within blocks considered random and with fixed effects for defoliation treatment, grazing date and interactions.

Results The sward herbage dry matter mass at grazing was $2407 \mathrm{~kg} / \mathrm{ha}$. The species identified were Lolium perenne (54.5\%), Dactylis glomerta (20.2\%), Phleum pratensis (10.9\%), Holcus lanatus (10.7\%), Alopecurus pratensis (1\%), Cerastium fontanum (1\%) Taracum officinale (1\%) and Trifolium repens $(0.5 \%)$ Poa annua $(0.1 \%)$ and Rumex obtusifolius $(0.1 \%)$. The effects of defoliation treatment, grazing date and herbage allowance on sward botanical composition is presented in Table 1. Delaying defoliation either by clipping or grazing tended to decrease the content of $L$. perenne. Delaying grazing from mid December to mid January tended to increase $(\mathrm{P}=0.06) P$. pratensis content. Increasing herbage allowance at grazing increased $H$. lanatus and decreased $P$. pratensis . Removing herbage by grazing at the low herbage allowance rather than clipping $(\mathrm{BvG})$ decreased H. lanatus.

Table 1 Effects of defoliation treatment on grazing date on herbage composition (\%) and yield

\begin{tabular}{|c|c|c|c|c|c|c|c|c|c|c|c|c|}
\hline & \multicolumn{4}{|c|}{ Defoliation treatment (DT) } & \multirow{2}{*}{\multicolumn{3}{|c|}{$\begin{array}{l}\text { Defoliation date } \\
\text { (D) }\end{array}$}} & \multirow{2}{*}{\multicolumn{2}{|c|}{ sig }} & \multirow{2}{*}{\multicolumn{3}{|c|}{ Contrasts }} \\
\hline & \multirow{2}{*}{\multicolumn{2}{|c|}{$\begin{array}{l}\text { Mowing } \\
\text { Early Dec At grazing } \\
\text { (A) } \quad \text { (B) }\end{array}$}} & \multicolumn{2}{|c|}{$\begin{array}{l}\text { Grazing }(G) \\
\text { allowance }\end{array}$} & & & & & & & & \\
\hline & & & 0.75 & 1.75 & Dec & Jan & Feb & $\overline{\mathrm{DT}}$ & $\mathrm{D}$ & $\mathrm{A} v \mathrm{~B}$ & $\begin{array}{l}0.75 v \\
1.75\end{array}$ & $\mathrm{BvG}$ \\
\hline L. perenne & 71 & 61 & 62 & 57 & 67 & 62 & 59 & $\mathrm{P}=0.11$ & $\mathrm{NS}$ & $\mathrm{P}=0.06$ & NS & NS \\
\hline D. glomerata & 16 & 18 & 21 & 27 & 18 & 21 & 22 & NS & NS & NS & NS & NS \\
\hline P. pratensis & 9 & 9 & 16 & 6 & 6 & 11 & 12 & $*$ & $\mathrm{P}=0.06$ & NS & $* *$ & NS \\
\hline H. lanatus & 6 & 10 & 2 & 9 & 8 & 5 & 6 & $*$ & NS & NS & $*$ & $\mathrm{P}=0.07$ \\
\hline $\begin{array}{l}\text { DM Yield } \\
(\mathrm{kg} / \mathrm{ha})\end{array}$ & 3655 & 3349 & 3573 & 4071 & 3842 & 3517 & 3626 & $* *$ & NS & $\mathrm{P}=0.08$ & $\mathrm{P}=0.07$ & \\
\hline
\end{tabular}

Conclusion Delaying defoliation either by clipping or grazing decreased the content of L. perenne primarily due to the effect of herbage mass rather than poaching during grazing. Consequently extended grazing has a negative impact on sward composition and subsequently reducing the reseeding interval.

\section{References}

Keady, T.W.J. and Hanrahan, J.P. 2009a. Effects of shearing at housing, grass silage feed value and extended grazing herbage allowance on ewe and subsequent lamb performance. Animal 3, 143-151.

Keady, T.W.J. and Hanrahan, J.P. 2009b. The effects of allowance and frequency of allocation of deferred herbage, and grass silage feed value, when offered to ewes in mid gestation on ewes and lamb performance and subsequent herbage yield. Animal 3, 879-890.

Keady, T.W.J., Hanrahan, J.P. and Flanagan, S. 2007. The effects of extended grazing during mid, late and throughout pregnancy, and winter shearing indoors, on ewe performance and subsequent lamb growth rate. Irish Journal of Agricultural and Food Research 46, 169-180.

Keady, T.W.J., Hanrahan, J.P. and Flanagan, S. 2009. An evaluation of two grassland based systems of mid season prime lamb production using prolific ewes. Irish Journal of Agricultural and Food Research 48, 87-102. 